\title{
Spatial and temporal variation in nearshore fish and macroinvertebrate assemblages from a temperate Australian estuary over a decade
}

\author{
G. Jackson ${ }^{1, *}$, G. K. Jones ${ }^{2}$ \\ ${ }^{1}$ Western Australian Marine Research Laboratories, PO Box 20, North Beach, Western Australia 6020, Australia \\ ${ }^{2}$ South Australian Research and Development Institute (Aquatic Sciences), PO Box 120, Henley Beach, South Australia 5022, \\ Australia
}

\begin{abstract}
Nearshore fish and macroinvertebrate assemblages of the Port River-Barker Inlet estuary South Australia, were sampled by beach seine at monthly intervals between January 1985 and December 1994. Multivariate analyses were used to determine patterns in species distribution and abundance, to determine the influence of site, month and year on assemblage structure, and to identify trends in species composition over the decade. A total of 403626 individuals representing 56 species were recorded, with Aldrichetta forsteri, Hyporhamphus melanochir, Sillaginodes punctata and Pelates octolineatus responsible for $76 \%$ of the total abundance. Estuarine-opportunistic species were consistently dominant over the decade with marine stragglers and estuarine-dependents important in some years only. Abundances of the 19 species determined to be dominant varied between years, with some species, e.g. Spratelloides robustus, Hyporhamphus regularis, Arenigobius bifrenatus, Nesogobius sp. 3 and Cristiceps australis, demonstrating considerably greater inter-annual variability compared with others, e.g. S. punctata, A. forsteri, H. melanochir, P. octolineatus, Haletta semifasciata and Sillago schomburgkii. The importance of temporal scale in any assessment of community stability is re-stated; although individual species varied in abundance between months and years, assemblage structure was shown to be reasonably stable over the decade. Water temperature and salinity were weakly correlated with patterns in species composition and abundance. Further experimental studies are required to improve ecological understanding of the system's fish fauna and on-going monitoring is necessary to assess future changes to fish populations in relation to adjacent wetland developments.
\end{abstract}

KEY WORDS: Estuarine fish - Assemblage structure S Spatial and temporal variability Community stability - Environmental influences . Southern Australia

\section{INTRODUCTION}

Although fish and macroinvertebrate assemblages of temperate nearshore marine environments, particularly estuaries, have been investigated in some detail, the duration of many studies has been only 1 or 2 yr at most, thereby limiting the description of patterns in species composition and abundance to the seasonal scale (Morin et al. 1985, Grossman 1986, Gibson et al. 1993, Tremain \& Adams 1995, Clark et al. 1996, Dye 1998). Variation in

•E-mail: gjackson@fish.wa.gov.au estuarine fish assemblage structure over the medium to long term is less well studied (Haedrich 1983) but nevertheless pivotal in any ecological assessment of how fishes use such environments. Studies of estuaries important to fishery production have demonstrated that seasonal and annual variation can only be identified after several years of sampling (Vance et al. 1996). However, few investigations of fish and macroinvertebrate faunas in estuaries or other nearshore habitats have been conducted over 5 yr or more; exceptions include Hillman et al. (1977), Yáñez-Arancibia et al. (1985), Potter et al. $(1986,1997)$, Loneragan \& Potter (1990), Yoklavich et al. (1991) and Dye (1998). 
The Port River-Barker Inlet system (138 $\left.30^{\prime} \mathrm{E}, 34^{\circ} 49^{\prime} \mathrm{S}\right)$ is the largest estuary in Gulf St Vincent, South Australia, covering approximately $20 \mathrm{~km}^{2}$ (Fig. 1). This offshoot from the gulf is a sheltered, marine-dominated environment which generally experiences 2 tides per day (maximum amplitude $\leq 2.5 \mathrm{~m}$ ). Habitats within the estuary include mud flats, mangroves and samphire marshes dissected by narrow channels (Butler et al. 1977). Low and intermittent inflows of freshwater, via ephemeral creeks and stormwater drains, coupled with high evaporation rates, are responsible for the maintenance of high salinities (generally $>35$ psu) throughout the system. Sediments range from coarse to fine sand (Thomas et al. 1986) with inter- and sub-tidal substrates supporting either seagrass, mainly Zostera muelleri and Heterozostera tasmanica, respectively, or no vegetation (Connolly 1994).

The proximity of Adelaide (population $>1$ million), and a history of extensive industrial activity in the surrounding region, has resulted in the estuary being subjected to many anthropogenic influences (Connolly 1994). Torrens Island is the site of an important seawater-cooled power station which has significant localised thermal influence on some of the estuary's fish species (Jones et al. 1996). Several sewage treatment plants release secondary stage effluent into the estuary, resulting in locally raised nutrient levels.
Between 1985 and 1994 sampling was undertaken to monitor the abundance of economically important teleosts that use the Port River-Barker Inlet estuary as a nursery area (Jones 1984). The resulting data provide an important opportunity to describe seasonal and annual variation in the assemblage structure of fish and macroinvertebrate faunas inhabiting this warmtemperate estuary. Using multivariate statistical techniques, the aims of this study were to (1) identify the species contributing to, and those dominating, the nearshore fish assemblages; (2) identify spatial (between sites) and temporal (between months and years) variation in species composition and abundance; (3) investigate inter-annual changes in the abundance of the consistently dominant species over the decade $e_{i}$ and (4) describe the relationship between certain environmental variables and assemblage structure.

The terms 'assemblage' and 'community' have been used with great flexibility in relation to ecological studies of fish faunas (Lasiak 1984, M. Wagner pers. comm.). 'Fish assemblage', as used here, includes teleosts, elasmobranchs and macroinvertebrates (only species of economic importance) and indicates taxa were coincident in time and space without reference to the strength of their interaction. Detailed analyses of the individual, economically important teleosts for
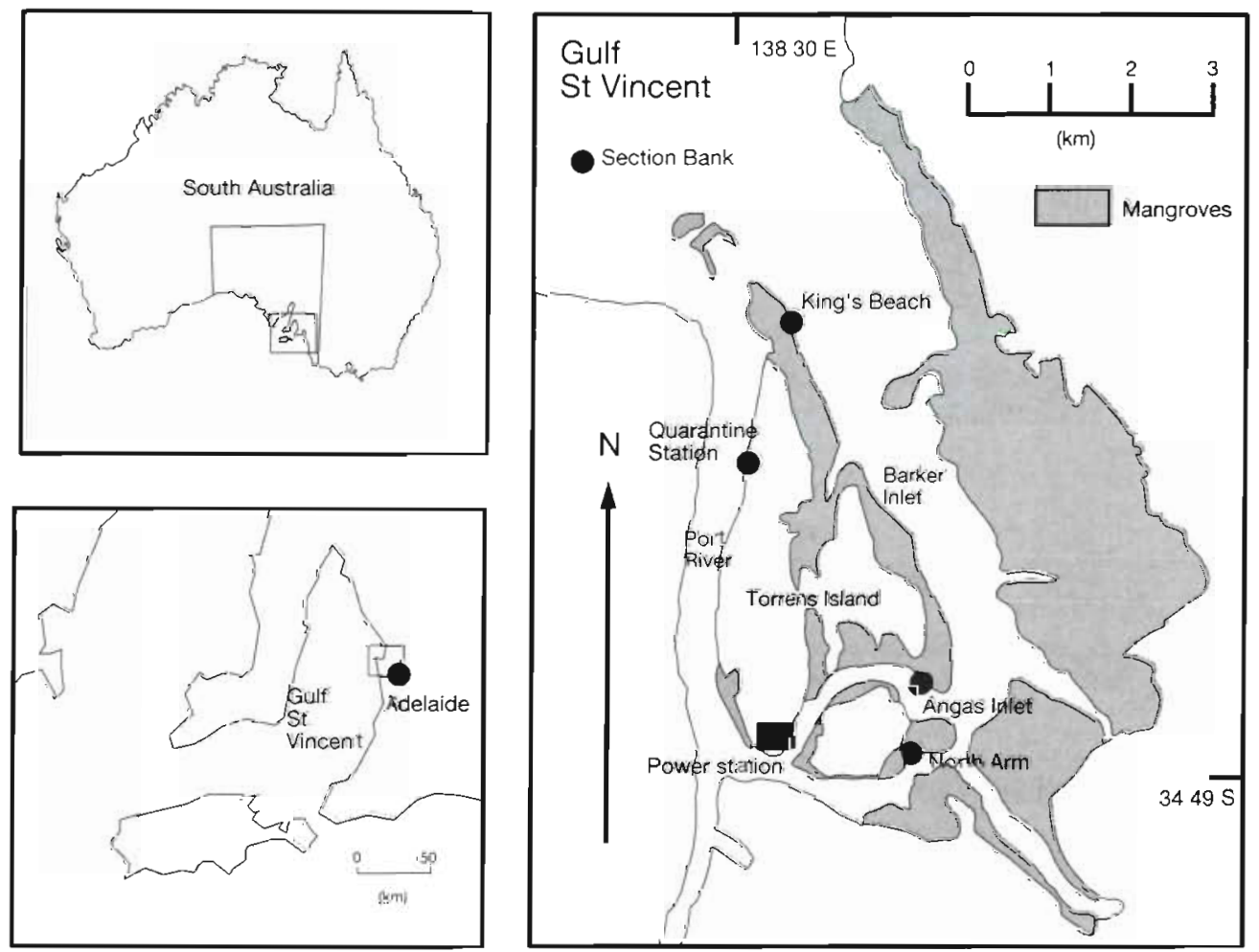

Fig. 1. The Port River-Barker Inlet estuary: location of sites (right), location of estuary in Gulf St Vincent (bottom left), and location of Gulf in South Australia (top left) 
which length-distribution data were collected ( $n=11$, see Table 2 ) are not included here, rather change at the 'community' level, over the decade, was of principal interest. The ecological concept of community stability, and the importance of temporal scale in the interpretation of results, is discussed in relation to these estuarine fish assemblages.

\section{MATERIALS AND METHODS}

Study sites. Five sampling sites were selected to reflect the range of habitats within the estuary (Fig. 1): (1) Section Bank represented the marine entrance to the estuary and consisted of a large, moderately mobile coarse sand bank supporting patches of Posidonia sp. (2) King's Beach consisted of sand- and mud-flats, the latter supporting Zostera sp., adjacent to a deeper channel. (3) Quarantine Station consisted of patches of sand and mud, the latter supporting Zostera sp., adjacent to a deeper, major shipping channel which has been modified by dredging. (4) Angas Inlet consisted of a large, mainly fine sand bank adjacent to a deeper channel and was the site most affected by thermal effluent (Jones et al. 1996). (5) North Arm consisted mainly of mud with a nearby large, shell-grit sand bank. All sites except Angas Inlet were subject to strong tidal flows. With the exception of Section Bank, all sites were adjacent to mangrove stands (Avicennia marina). Extensive areas of the floating macroalga Ulva australis were seasonally present (Connolly 1986). King's Beach, North Arm and Angas Inlet were more consistently sampled than either Quarantine Station or Section Bank (Table 1).

Sampling methods. Monthly sampling was conducted between January 1985 and December 1994. All sampling was undertaken during the day and involved a single net haul, at each site, at slack low water (spring tide), with water depth generally $\leq 3 \mathrm{~m}$. The same multifilament beach seine (18 ply), of $120 \mathrm{~m}$ length and $2.5 \mathrm{~m}$ drop, was used throughout the survey period and comprised two $30 \mathrm{~m}$ wings $(3 \mathrm{~cm}$ mesh) with a $60 \mathrm{~m}$ central bunt ( $1 \mathrm{~cm}$ mesh). At each site, the net was set in a semi-circle from a $6 \mathrm{~m}$ planing-hull boat and then gradually hauled ashore, closing the net and herding the fish into the bunt. Fish were transferred to a holding cauf (1 cm mesh), identified and counted, with only the economically important species measured (caudal fork length, nearest $\mathrm{cm}$ ), where $>100$ individuals of a species were caught a random sub-sample only was measured. At each site water temperature (at depth $\sim 30 \mathrm{~cm}$ ) was recorded and a water sample taken for salinity deter- mination using an 'Autolab' salinometer. No other environmental variables were quantitatively measured during the study.

Data analysis. Multivariate analyses of assemblage structure and its relationship with environmental data were undertaken using the CLUSTER, MDS, SIMPER, ANOSIM2, and BIOENV options of the PRIMER software (version 4-beta, Plymouth Marine Laboratory, Plymouth, UK) (Clarke \& Warwick 1994). Species of fish were identified according to Hutchins \& Swainston (1986) and Gomon et al. (1994). Although 56 species were recorded during the entire study, the decision was made to include only 30 in these analyses (Field et al. 1982, Clarke \& Warwick 1994); taxa recorded less than once per month during the 10 yr (i.e. total number of recordings $<120$ ) were excluded. Additionally, due to some inconsistencies in field identification, 6 of the smaller teleosts were combined in the following: Kestratherina esox and Atherinosoma microstoma as 'atherinids', Kaupus costatus and Stigmatopora argus as 'syngnathids', and Meuschenia freycineti and Brachaluteres jacksonianus as 'monacanthids'. The resulting 3 'family' groups were then treated as single taxa (see Table 2).

Individual species abundances were converted to densities per $100 \mathrm{~m}^{2}$ (using an average area of $2290 \mathrm{~m}^{2}$ swept by each haul, see Jones et al. 1996) prior to construction of conventional matrix arrays. The arrays were arranged into 2 formats to allow the testing of specific hypotheses. To test for differences between sites and months in each year, 10 'year' matrices (1985 to 1994) were constructed with rows = species and columns $=$ site $/$ month samples. To test for differences between years, 4 'site' matrices (King's Beach, North Arm, Angas Inlet and Quarantine Station) were constructed with rows $=$ species and columns $=$ month $/$ year samples. Section Bank was excluded from this latter analysis as sampling had occurred on only $50 \%$ of possible occasions over the study period (Table 1). 
Fourth-root transformed biotic data were converted to triangular matrices of similarities between every pair of samples using the Bray-Curtis similarity coefficient. Similarities between samples were graphically represented by dendrograms (with comparisons made at the $30 \%$ Bray-Curtis similarity level) and ordination plots using multidimensional scaling (MDS).

Species principally responsible for sample groupings in each of the 10 'year' arrays were identified using SIMPER (Clarke \& Warwick 1994). Those contributing to $90 \%$ of the total average similarity within sites (defined as typical of those sites) and $90 \%$ of the total average dissimilarity between sites (defined as species discriminating between sites) were determined. To allow comparison of the species contributions between years both average similarity (averaged across all sites sampled in each year) and average dissimilarity (averaged across all pairs of site-samples in each year) were calculated for these species only. From this, the species most consistently contributing over the decade were identified ( $n=19$, see Table 4 ) and the inter-annual variation in their contribution determined. Mean annual abundances (averaged across all sites sampled in each year) of the consistently dominant species were calculated to identify any trends in abundance. In the context of southern Australia, 4 seasons were defined as: summer (December to February), autumn (March to May), winter (June to August) and spring (September to November).

The non-parametric ANOSIM2 test for a 2-way (crossed) layout without replication uses a randomization test to compare ranked similarities between and within groups selected a priori, and was conducted on the 10 'year' (groups: month and site) and 4 'site' matrices (groups: month and year), with each test involving 5000 simulations.

Mean monthly water temperatures and salinities were plotted against time for each site. Biotic and abiotic similarity matrices (the latter compiled in a similar manner to the species density data and involved all possible combinations of the environmental samples using the BrayCurtis coefficient) were compared using the BIOENV procedure which uses weighted Spearman rank coefficients to assess agreement between patterns in the biotic and abiotic data (Clarke \& Warwick 1994). At the time of analysis no test of significance for the BIOENV correlations was available and the procedure was considered an exploratory tool only (Clarke \& Warwick 1994).

\section{RESULTS}

\section{Species composition and abundance}

A total of 403626 individuals representing 56 species were recorded: 45 teleosts ( 31 families), 4 elasmobranchs ( 3 families), 3 cephalopods and 4 crustaceans (Table 2).

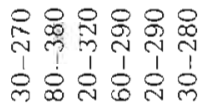

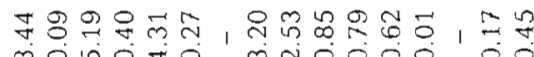

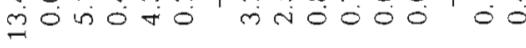

$-\stackrel{\pi}{\pi}$ M

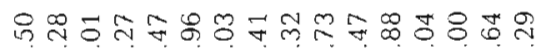

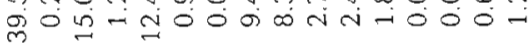

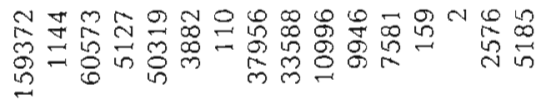

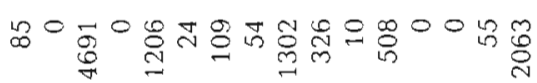

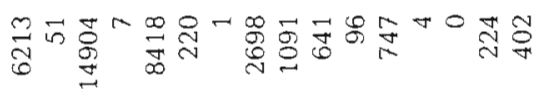

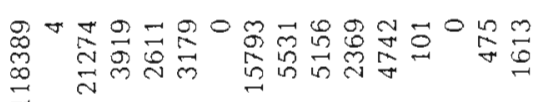

$\stackrel{\infty}{=}$

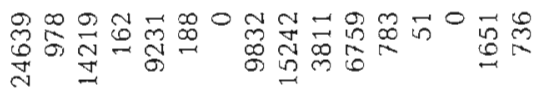

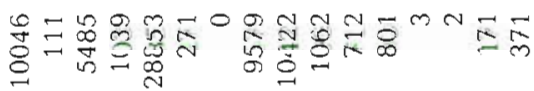

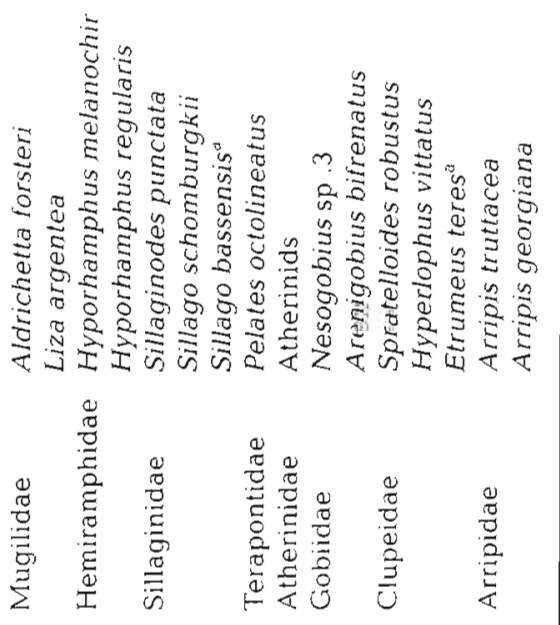




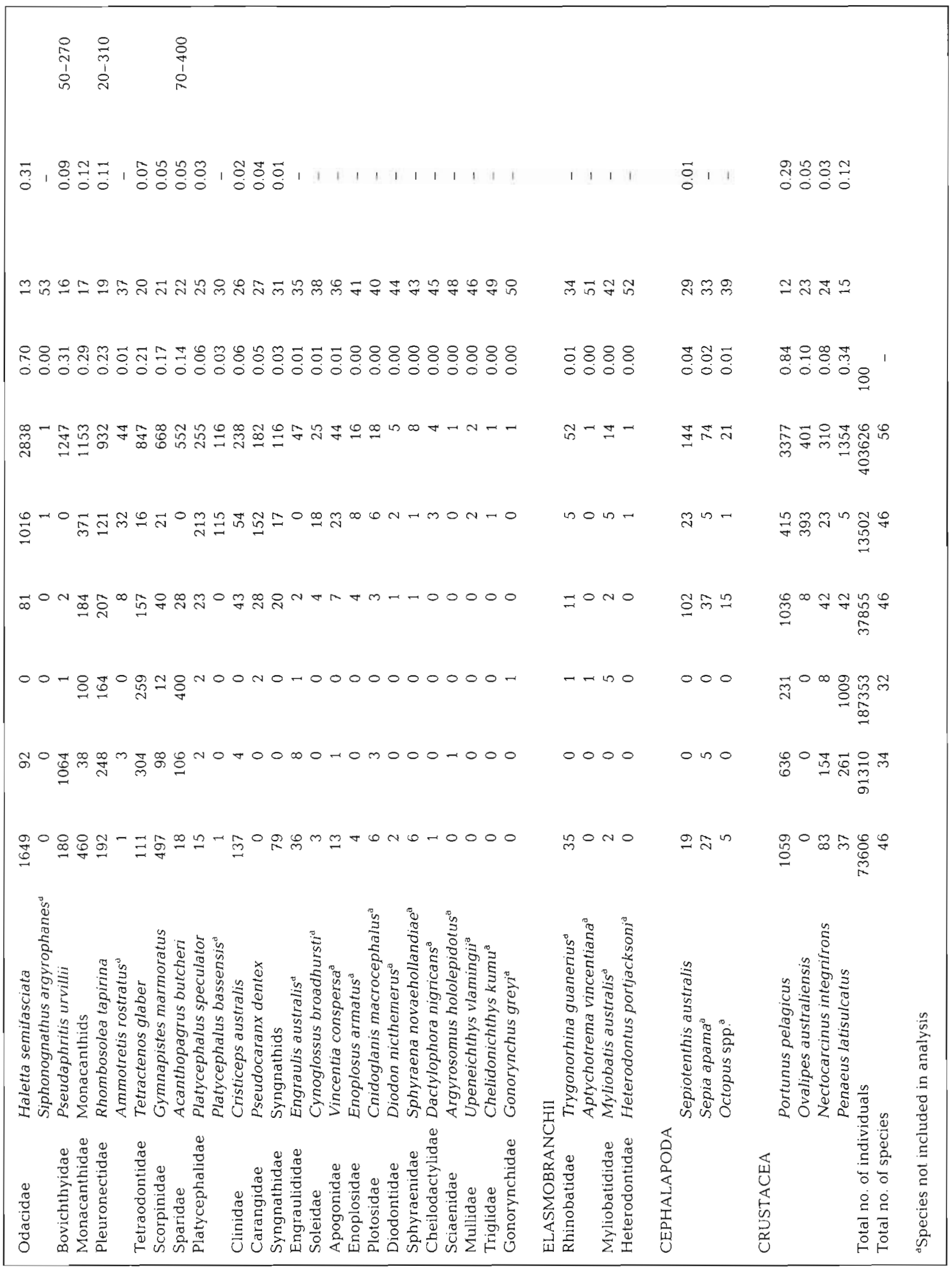


Four species of teleost were responsible for $76 \%$ of the total abundance: Aldrichetta forsteri (39.5\%), Hyporhamphus melanochir (15\%), Sillaginodes punctata $(12.5 \%)$ and Pelates octolineatus $(9.4 \%$ ) (Table 2 ). The number of species recorded decreased moving into the estuary, with 46 species found at King's Beach, Quarantine Station and Section Bank, and 34 and 32 at North Arm and Angas Inlet, respectively. The species which together contributed $\geq 80 \%$ of the total abundance at each site were all teleosts, with species contribution varying between sites; $A$. forsteri, $H$. melanochir, $S$. punctata and $P$. octolineatus were the main contributors at 4 of the 5 sites, atherinids at 3 sites, while Arripis georgiana, Haletta semifasciata and Spratelloides robustus were important only at Section Bank (Table 3).

\section{Dominant species}

A total of 19 species (of the 30 included in the analysis) were considered to be dominant, i.e. together contributing $\geq 90 \%$ of the average within-site similarity and average between-site dissimilarity in each year, and included teleosts and macroinvertebrates (Table 4). Of greatest influence were Aldrichetta forsteri, Hyporhamphus melanochir, Sillaginodes punctata and atherinids, which were also the most abundant species (Table 3). Pelates octolineatus, Haletta semifasciata, Rhombosolea tapirina, Portunus pelagicus, Nesogobius sp. 3 and Arenigobius bifrenatus were also consistently important. Arripis georgiana, Arripis truttacea, Sillago schomburgkii, monacanthids, Ovalipes australiensis, Pseudaphritis urvillii and Spratelloides robustus were important contributors in some years only.

Ovalipes australiensis, Platycephalus speculator and Cristiceps australis were identified as true discriminating species at Section Bank, Rhombosolea tapirina and Penaeus latisulcatus at Quarantine Station, Hyporhamphus regularis at Angas Inlet and Pseudaphritis urvillii at King's Beach.

\section{Inter-annual variation of dominant species}

All of the 19 dominant species demonstrated some inter-annual variation in abundance, the magnitude of which differed considerably between species (Figs. 2 \& 3). Teleosts were grouped by this variability into groups of species whose mean annual abundance varied by a factor of 1 to 10 (Sillaginoides punctata, Sillago schomburgkii, Aldrichetta forsteri, Hyporhamphus melanochir, Haletta semifasciata, and Pelates octolineatus), 10 to 20 (Arripis truttacea, Arripis georgiana, monacanthids, Pseudaphritis urvillii and atherinids), 20 to 50 (Spratelloides robustus, Hyporhamphus regularis, Arenigobius bifrenatus and Cristiceps australis) and $>100$ (Nesogobius sp. 3). Variation in the abundance of macroinvertebrates ranged between a factor of 1 to 10 (Ovalipes australiensis) and 10 to 20 (Penaeus latisulcatus, Portunus pelagicus).

Peaks in abundance for a number of species occurred in the same year, e.g. Sillaginoides punctata, Aldrichetta forsteri, Arripis truttacea and Rhombosolea tapirina (1990), Sillago schomburgkii, A. forsteri, Hyporhamphus melanochir and Portunus pelagicus (1991), and atherinids, Nesogobius sp. 3, Arenigobius bifrenatus, $H$. regularis, $H$. melanochir, Pelates octolineatus and Pseudaphritis urvillii (1993).

\section{Spatial and temporal differences in assemblage structure}

'Year' arrays

Dendrograms and ordinations developed for the 10 'year' matrices produced moderately defined groupings of species samples (Fig. 4). At the $30 \%$ similarity level, the number of clusters varied between years from 2 (1990 and 1991) to 6 (1988). Section Bank samples formed a distinct cluster in most years (with the exception of 1990 and 1993) while Angas Inlet (partic-

Table 3 . Species together contributing $\geq 80 \%$ of total abundance at each site, pooled across years, 1985 to 1994 . See Table 2 for full species names

\begin{tabular}{|c|c|c|c|c|c|c|c|c|c|c|}
\hline & \multirow{2}{*}{\multicolumn{2}{|c|}{$\begin{array}{c}\text { King's Beach } \\
\mathrm{n}\end{array}$}} & \multicolumn{2}{|c|}{ North Arm } & \multicolumn{2}{|c|}{ Angas Inlet } & \multicolumn{2}{|c|}{ Quarantine Station } & \multicolumn{2}{|c|}{ Section Bank } \\
\hline & & & $\mathrm{n}$ & $\%$ & $\mathrm{n}$ & $\%$ & $\mathrm{n}$ & $\%$ & $\mathrm{n}$ & $\%$ \\
\hline S. punctata & 28853 & 39.2 & 9231 & 10.1 & & & 8418 & 22.2 & 1206 & 8.9 \\
\hline A. forsteri & 10046 & 13.6 & 24639 & 27 & 118389 & 63.2 & 6213 & 16.4 & & \\
\hline P. octolineatus & 9579 & 13 & 9832 & 10.8 & 15793 & 8.4 & 2698 & 7.1 & & \\
\hline Atherinids & 10422 & 14.2 & 15242 & 16.7 & & & & & 1302 & 9.6 \\
\hline H. melanochir & & & 14219 & 15.6 & 21274 & 11.4 & 14904 & 39.4 & 4691 & 34.74 \\
\hline A. georgiana & & & & & & & & & 2063 & 15.4 \\
\hline H. semifasciata & & & & & & & & & 1016 & 7.6 \\
\hline S. robustus & & & & & & & & & 508 & 3.8 \\
\hline Total & 58900 & 80 & 73163 & 80.2 & 1.55456 & 83 & 32233 & 85.1 & 10786 & 80 \\
\hline
\end{tabular}


Table 4. Average similarity (pooled across all sites) and average dissimilarity (pooled across all pairs of sites) for 1985 to 1994 (see 'Materials and methods: Data analysis'). Only species which together contributed $\geq 90 \%$ of total similarity and dissimilarity are included, i.e. those considered dominant. Values presented are unitless and derived from SIMPER tables generated for each year (not presented). See Table 2 for full species names

\begin{tabular}{|c|c|c|c|c|c|c|c|c|c|c|}
\hline & 1985 & 1986 & 1987 & 1988 & 1989 & 1990 & 1991 & 1992 & 1993 & 1994 \\
\hline \multicolumn{11}{|l|}{ Average similarity } \\
\hline A. forsteri & 21.98 & 15 & 19.65 & 21.72 & 20.97 & 29 & 17.28 & 15.9 & 10.99 & 13.24 \\
\hline H. melanochir & 14.66 & 10.39 & 13.63 & 10.59 & 18.69 & 18.87 & 14.27 & 11.19 & 19.35 & 18.47 \\
\hline S. punctata & 10.47 & 18.9 & 26.99 & 27.97 & 6.31 & 10.68 & 13.9 & 7.95 & 10.52 & 9.62 \\
\hline S. schomburgkii & 7.37 & 3.53 & & 1.81 & & & & 3.18 & & \\
\hline Atherinids & 8.74 & 7.07 & 3.19 & 2.72 & 6.11 & 5.74 & 4.4 & 5.66 & 13.23 & 9.61 \\
\hline P. octolineatus & 1.08 & & 4.4 & 3.21 & 4.68 & 5.56 & 4.64 & & & 3.61 \\
\hline A. truttacea & & & & & 1.71 & 2.94 & 5.87 & & & \\
\hline A. georgiana & 14.4 & & 5.29 & 4.14 & 4.63 & & 3.39 & & & \\
\hline Monacanthids & & & & & & & & & 2.15 & 3.04 \\
\hline S. robustus & & & & & & & & & & 3.73 \\
\hline H. semifasciata & 1.72 & & & 7.34 & & 1.78 & 4.6 & 6.41 & 3.24 & 2.44 \\
\hline A. bifrenatus & 3.93 & 4.76 & 1.96 & & & 4.53 & & 5.77 & 3.34 & \\
\hline Nesogobius sp. 3 & & 4.22 & & & & 1.45 & & 8.22 & 8.7 & 3.77 \\
\hline R. tapirina & & 6.21 & 2.98 & 1.08 & & & 2.48 & 3.4 & & \\
\hline P. pelagicus & & 4.24 & & & 1.87 & & 9.14 & 13.1 & 8.12 & 12.12 \\
\hline O. australiensis & & 3.41 & 4.8 & 1.86 & 8.91 & & & & & \\
\hline \multicolumn{11}{|l|}{ P. latisulcatus } \\
\hline H. regularis & 1.19 & & 1.88 & & 3.12 & 4.27 & & & & \\
\hline P. urvillii & & & & & & & & & 3.15 & \\
\hline \multicolumn{11}{|c|}{ Average dissimilarity } \\
\hline A. forsteri & 9.2 & 11.93 & 10.72 & 12.88 & 15.24 & 7.97 & 12.53 & 9.18 & 8.4 & 9.51 \\
\hline H. melanochir & 9.76 & 6.98 & 7.89 & 10.54 & 9.14 & 10.43 & 7.85 & 5.99 & 8.94 & 7.49 \\
\hline S. punctata & 8.97 & 8.2 & 9.6 & 11.5 & 8.96 & 9.06 & 6.88 & 6.98 & 7.25 & 6.53 \\
\hline S. schomburgkii & 4.7 & 3.93 & & & 3.82 & & 4.53 & 3.91 & & \\
\hline Atherinids & 8.11 & 7.45 & 6.64 & 5.43 & 8.41 & 6.7 & 7.23 & 5.89 & 10.1 & 8.82 \\
\hline P. octolineatus & 7.49 & 5.5 & 6.99 & 8.35 & 6.57 & 7.82 & 6.89 & 3.64 & 6.38 & 6.62 \\
\hline A. truttacea & & & & & 3.53 & 4.12 & 3.68 & & & \\
\hline A. georgiana & 7.55 & & 5.33 & 7.38 & 6.03 & 4.58 & & & & \\
\hline Monacanthids & & & & & & & & & 3.47 & 3.87 \\
\hline S. robustus & & 4.06 & & & & & & & & 5.97 \\
\hline H. semifasciata & 3.22 & & & 4.41 & & & 4.13 & 5.74 & & \\
\hline A. bifrenatus & 6.1 & 6.95 & 4.03 & 2.68 & & 5.35 & & 5.96 & 5.04 & 3.42 \\
\hline Nesogobius sp. 3 & & 4.2 & & & 3.53 & & 4.19 & 6.45 & 7.28 & 5.72 \\
\hline R. tapinina & 4.76 & 3.97 & 3.19 & 2.98 & & 4.8 & & & 2.46 & \\
\hline P. pelagicus & & & & 3.13 & & & 5.06 & 3.65 & 3.89 & 4.69 \\
\hline \multicolumn{11}{|l|}{ O. australiensis } \\
\hline P. latisulcatus & & & 3.23 & & & & & & & \\
\hline H. regularis & & & & & 3.4 & 4.26 & & & 2.97 & \\
\hline P. urvillii & & & 3.3 & & & & & & 3.69 & 3.17 \\
\hline
\end{tabular}

ularly in spring and summer) and King's Beach (in winter) clustered to a lesser extent. Dendrogram patterns were well supported by MDS groupings in all years, with samples from Section Bank and Angas Inlet/North Arm consistently furthest apart, implying that assemblage structure was more different between these sites than others. Stress values in 2 dimensions (2-D), a measure of the 'goodness of fit' of the ordinations, varied between 0.15 (1989) and 0.24 (1986 and 1993). Three-dimensional (3-D) stress values were lower - as would be expected - ranging between 0.11 (1989) and 0.17 (1993). Such values indicated that the ordinations were potentially useful for pattern interpretation when used in conjunction with the relevant dendrograms (Clarke \& Warwick 1994).
ANOSIM2 tests resulted in significant differences $(\alpha=0.05$ ) between the sites in 7 of the 10 years (Table 5). Differences between months, pooled across sites, were only significant in 1988 and 1993.

\section{'Site' arrays}

Dendrograms and ordinations developed from the 4 'site' matrices resulted in less-well-defined patterns (not presented); 2-D stress values were between 0.24 and 0.28 , and 3 -D values between 0.18 and 0.21 . However, ANOSIM2 tests identified significant variation between years at North Arm and Angas Inlet. There was also considerable variation between months, 

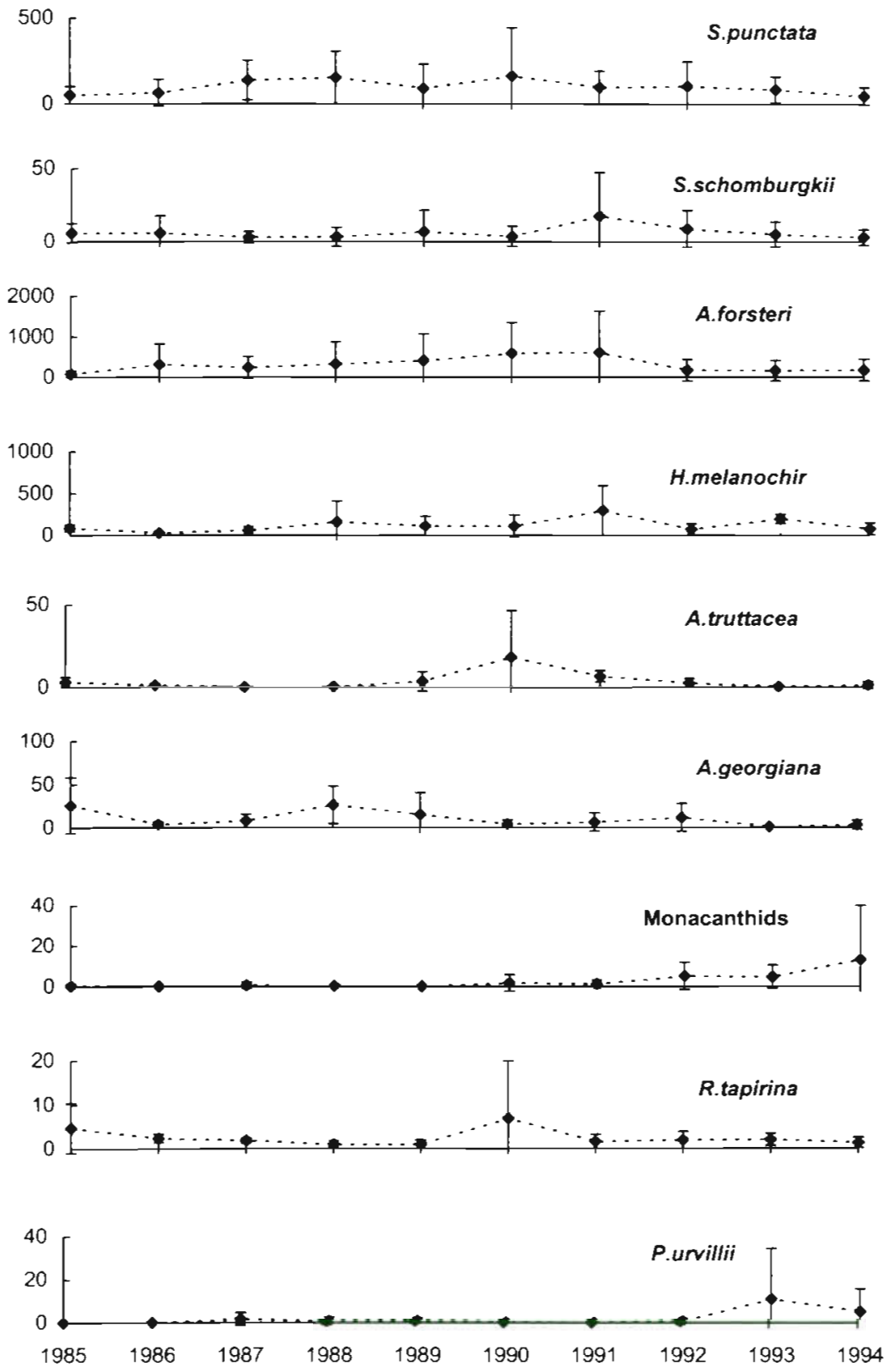

Fig. 2. Mean annual abundances (pooled across all sites) of the dominant teleosts of economic importance, 1985 to 1994. Vertical. axes are numbers of individuals - note different scales. Error bars are standard error

pooled across years, at King's Beach, North Arm and Quarantine Station (Table 5).

\section{Environmental factors - water temperature and salinity}

The highest temperatures were recorded at Angas Inlet (maximum $33.9^{\circ} \mathrm{C}$, summer 1985 and 1990 ) and the lowest at North Arm (minimum 10.6 $6^{\circ} \mathrm{C}$, winter 1993) (Fig. 5). North Arm also experienced the greatest range of temperature $\left(10.6\right.$ to $30.6^{\circ} \mathrm{C}$, mean $\left.20^{\circ} \mathrm{C}\right)$ and Section Bank the smallest $\left(12.6\right.$ to $26.4^{\circ} \mathrm{C}$, mean $13.8^{\circ} \mathrm{C}$ ). The thermal influence of Torrens Island Power Station was apparent at the 2 most affected sites, i.e. Angas Inlet and North Arm, with temperatures consistently higher, in all months, than at other sites.

Salinity ranges (psu) were broadly similar for all sites with the exception of King's Beach: 30.44 to 41.66 (King's Beach), 33.98 to 40.45 (Angas Inlet), 33.1 to 39.88 (North Arm), 34.5 to 39.87 (Section Bank) and 34.21 to 39.41 (Quarantine Station) (Fig. 6). Lower than average salinities were recorded in late 1987 (summer, North Arm), mid 1991 (spring, King's Beach and North Arm) and at all sites in late 1992 (spring, particularly King's Beach) and were likely the result of major rainfall events.

\section{Relationships between biotic and environmental variables}

BIOENV correlation values were extremely low for both salinity and temperature considered separately, and both variables combined, in all years (Table 6). Water temperature appeared to group the samples better than salinity, in a manner consistent with the biotic patterns, in all years except 1985 and 1994. The salinity + temperature combination produced correlations higher than those resulting when each variable was considered separately in only 4 of the 10 years, i.e. 1985, 1986, 1990 and 1994 .

\section{DISCUSSION}

\section{Nearshore fish assemblage structure}

The Port River-Barker Inlet estuary supports large abundances of nearshore fishes. Diversity is generally low $(<100$ species, Kennish 1990) and the assemblage structure is dominated by relatively few species. Such patterns are typical of temperate estuaries and embayments, with the numbers of families and taxa recorded comparable with those found in Australia (Bell et al. 1984, Loneragan et al. 1986, 1989, Loneragan \& Potter 1990, Humphries et al. 1992, Potter et al. 1993, Potter \& Hyndes 1994, Edgar \& Shaw 1995a, Jenkins et al. 1997a) and elsewhere (Horn 1980, Haedrich 1983, De Ben et al. 1990, Kennish 1990, Yoklavich et al. 1991, Tremain \& Adams 

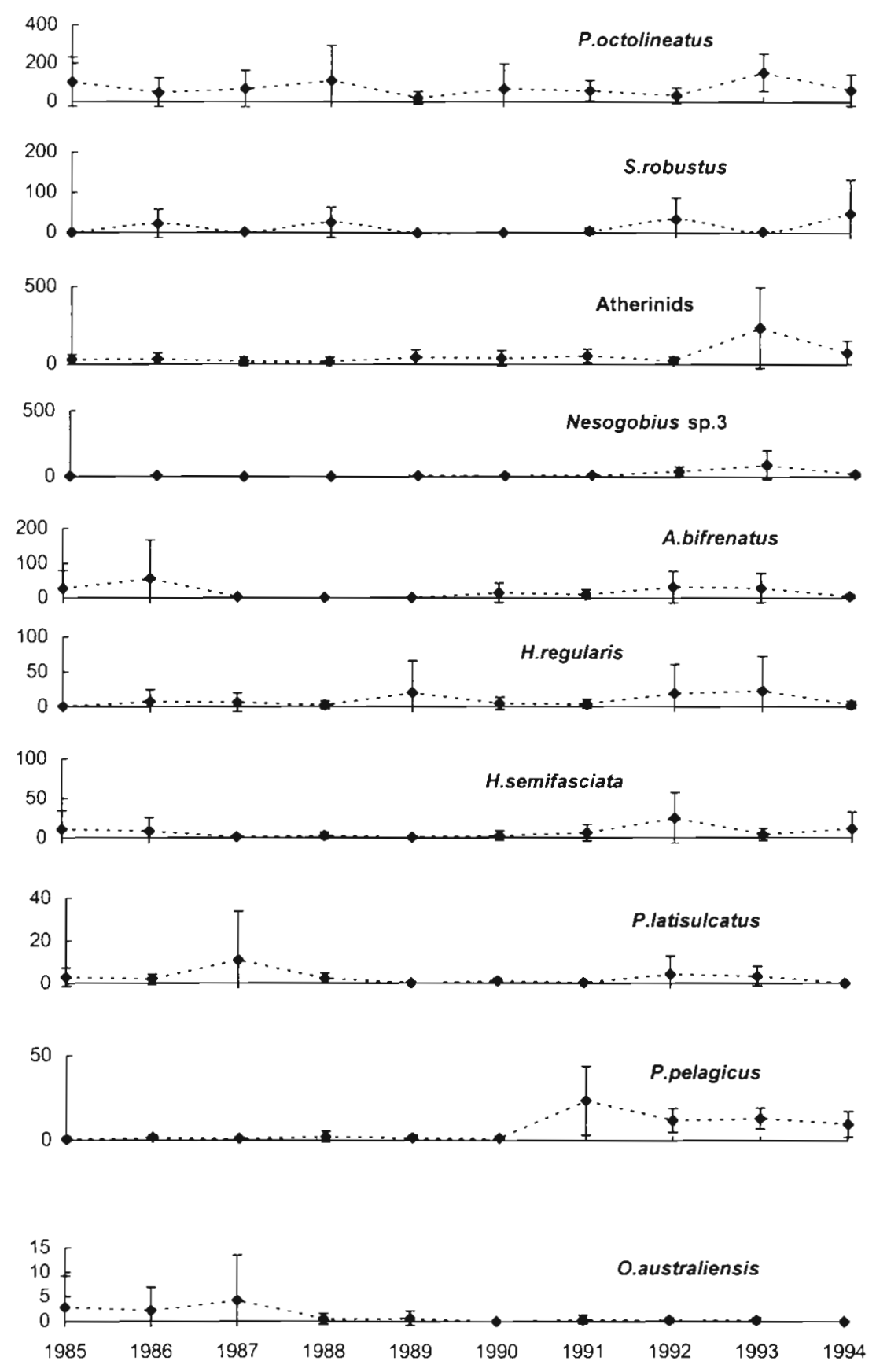

Fig. 3. Mean annual abundances (pooled across all sites) of the dominant crustaceans and teleosts not of economic importance, 1985 to 1994. Vertical axes are numbers of individuals-note different scales. Error bars are standard error

1995). There was no sampling at night nor in deeper channel habitats and therefore the total number of species recorded may be an underestimate. The numbers of species recorded were greatest at the 'mid' and 'outer' sites, i.e. Quarantine Station, King's Beach and Section Bank, and lower at the 'inner' sites, i.e. Angas
Inlet and North Arm. This is consistent with other temperate estuaries where the numbers of species decrease moving into the estuary (Horn \& Allen 1985, Potter et al. 1986, Kennish 1990, Loneragan \& Potter 1990).

The role of estuaries in providing habitat for juveniles and adults of economically valuable species is well accepted (Haedrich 1983, Bell et al. 1984, Kennish 1990, Loneragan \& Potter 1990, Potter et al. 1990). Here $67 \%$ of all individuals caught were considered to be of economic value, supporting the findings of Jones et al. (1996).

Life-history pattern (Lenanton \& Potter 1987) has been identified as an important factor determining species distribution and abundance in the Port River-Barker Inlet system (Jones et al. 1996) as elsewhere (Loneragan et al. 1989, Potter et al. 1990, 1993, 1997, Yoklavich et al. 1991). Although the estuary lacks the well- defined environmental gradients typical of other systems, species distribution patterns are, in terms of life-history, consistent with those of true estuaries (as defined by Day 1981). Lenanton \& Potter (1987) categorised species that frequent estuaries as either estuary-dependents (confined to estuaries for their entire lifecycle), estuary-opportunists (enter estuaries as juveniles but the estuary is not essential to the species' long-term success) or marine stragglers (enter estuaries irregularly and generally in low numbers).

Estuarine-opportunists dominate the Port River-Barker Inlet nearshore fish fauna, e.g. Aldrichetta forsteri, Sillaginodes punctata, Hyporhamphus melanochir, Pelates octolineatus, Portunus pelagicus, Arripis georgiana, Arripis truttacea, Sillago schomburgkii and Rhombosolea tapirina. Both marine stragglers, including 1 species of atherinid, Haletta semifasciata, and Spratelloides robustus, and estuarine-dependents, including Pseudaphritis urvillii, Arenigobius bifrenatus, Nesogobius sp. 3 and 1 species of atherinid, were important contributors but to a lesser extent than estuarine-opportunists. Species identified as discriminators between the sites were either marine stragglers, i.e. Ovalipes australiensis, Platycephalus speculator and Cristiceps australis (at Section Bank), estuarine-opportunists, i.e. $R$. tapirina and Penaeus 


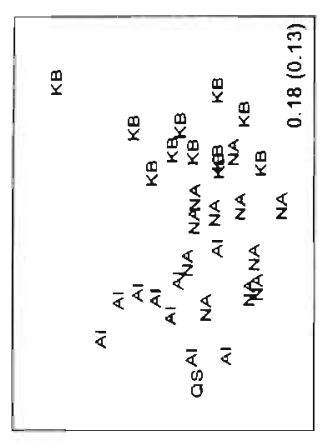

皓

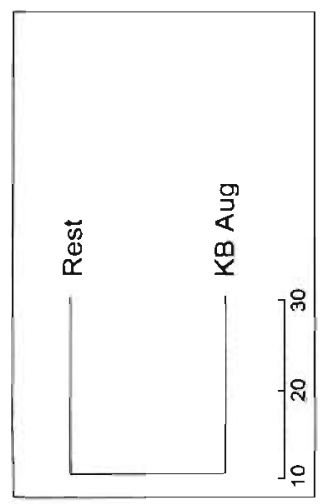

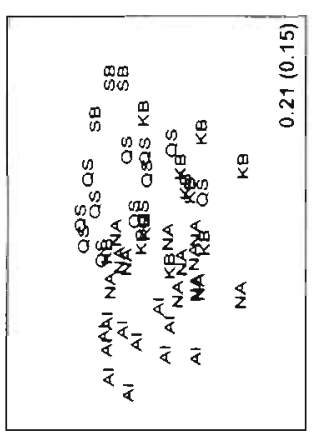

ฐ

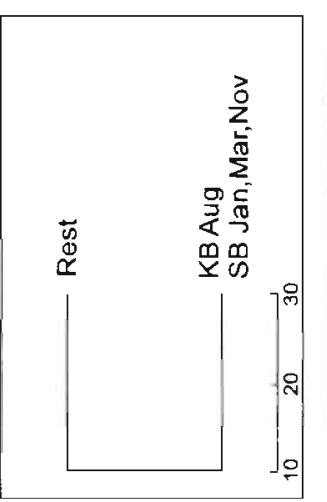

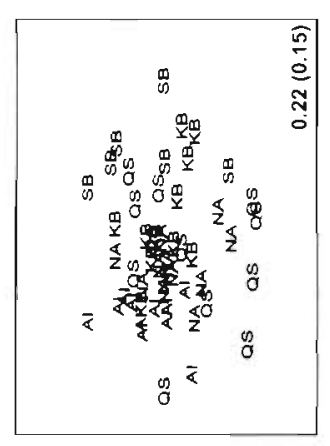

䄈

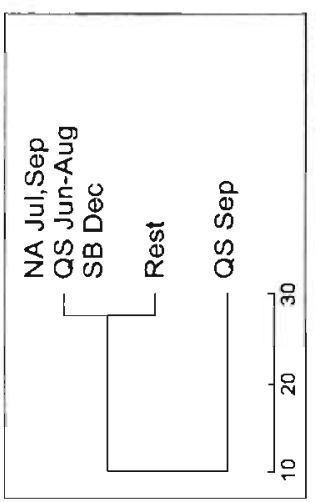

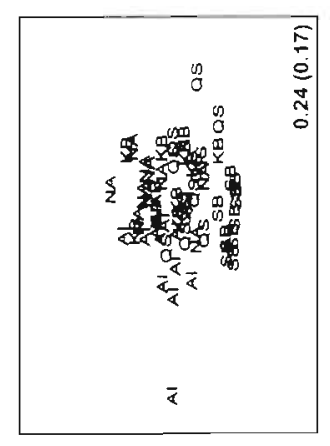

g

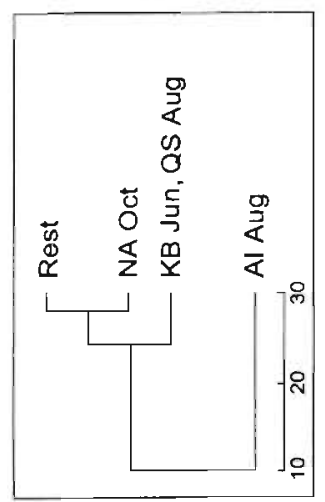

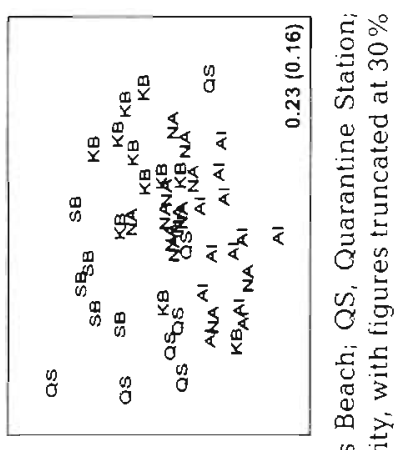

兽

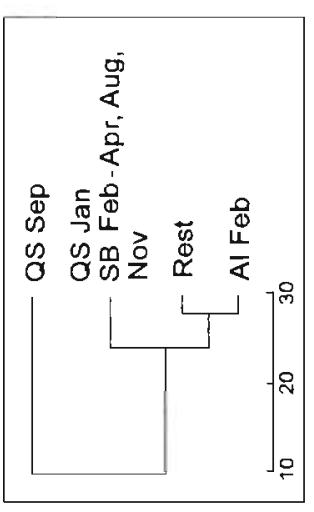

o.

结

gin

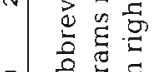

可

送

n

동

品亦

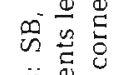

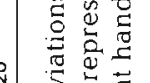

.

ฮृ

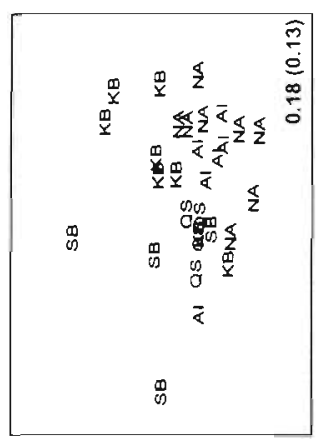

量

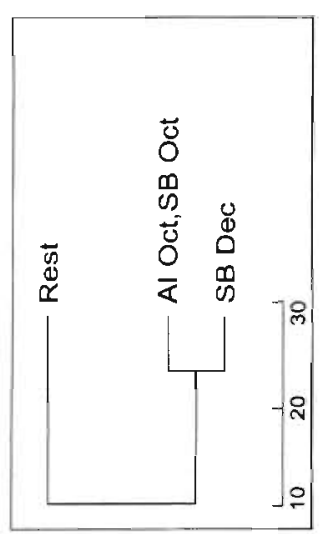

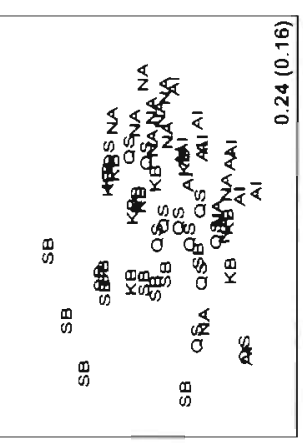

$\stackrel{\mathscr{O}}{\mathscr{\sigma}}$

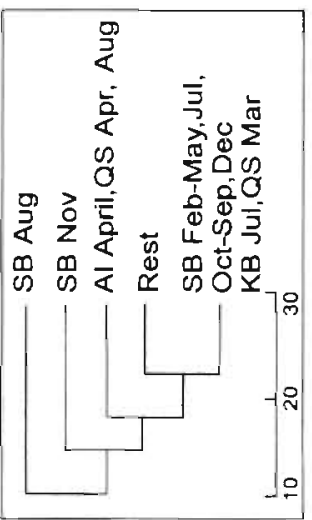

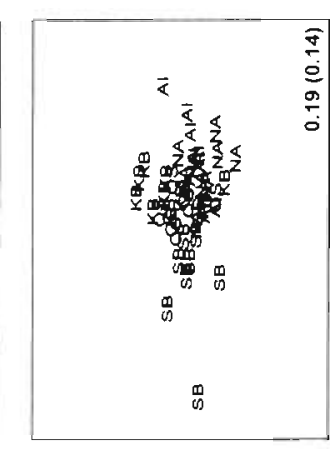

$\stackrel{\stackrel{\infty}{\circ}}{\stackrel{9}{9}}$

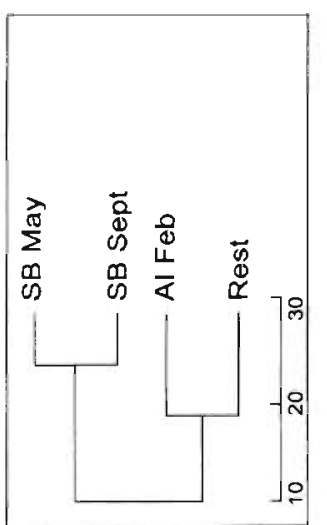

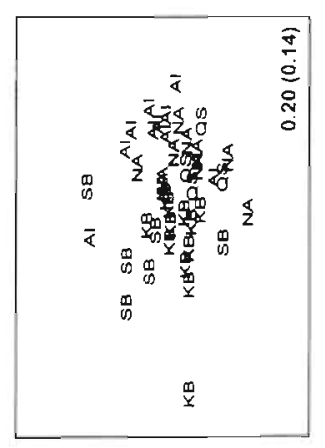

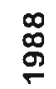

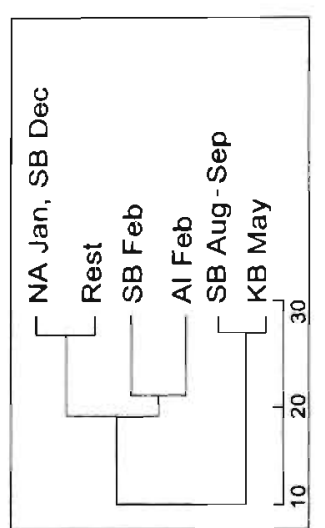
$\stackrel{\square}{\Xi} \Xi$

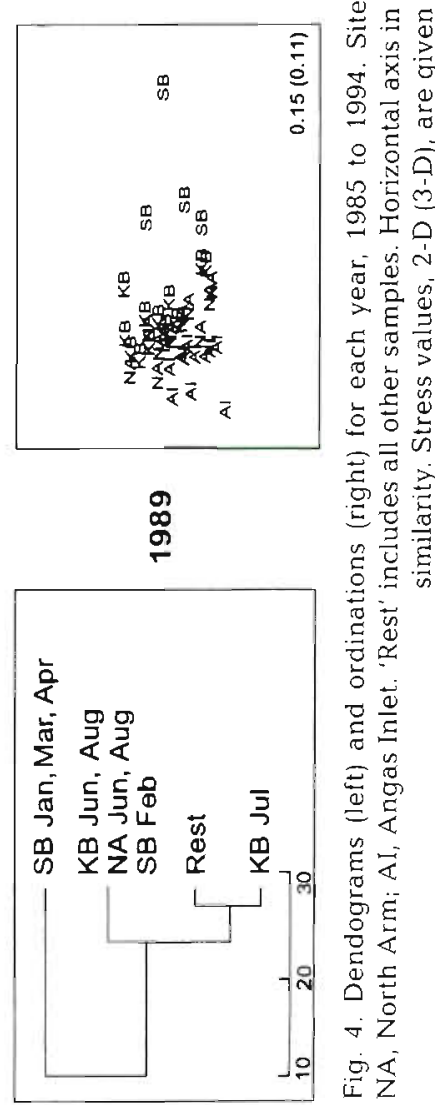


Table 5. ANOSIM2 results for tests on (a) the 10 'year' arrays (differences between sites, pooled across months, and differences between months, pooled acoss sites) and (b) the 4 'site' arrays (differences between years, pooled across months, and differences between months, pooled across years) ns: nonsignificant probabilities at the 0.05 level

\begin{tabular}{|lcc|}
\hline $\begin{array}{l}\text { (a) 'Year' arrays } \\
\text { Year }\end{array}$ & $\begin{array}{c}\text { Differences } \\
\text { between sites }\end{array}$ & $\begin{array}{c}\text { Differences } \\
\text { between months }\end{array}$ \\
\hline 1985 & $0.14 \mathrm{~ns}$ & $0.21 \mathrm{~ns}$ \\
1986 & 0.0002 & $0.09 \mathrm{~ns}$ \\
1987 & 0.003 & $0.68 \mathrm{~ns}$ \\
1988 & $0.07 \mathrm{~ns}$ & 0.005 \\
1989 & 0.03 & $0.56 \mathrm{~ns}$ \\
1990 & $0.11 \mathrm{~ns}$ & $0.39 \mathrm{~ns}$ \\
1991 & 0.013 & $0.12 \mathrm{~ns}$ \\
1992 & 0.002 & $0.45 \mathrm{~ns}$ \\
1993 & 0.004 & 0.003 \\
1994 & 0.014 & $0.35 \mathrm{~ns}$ \\
& & \\
(b) 'Site' arrays & Differences & Differences \\
Site & between years & between months \\
& $0.07 \mathrm{~ns}$ & 0 \\
\hline King's Beach & 0.002 & 0.032 \\
North Arm & 0.009 & $0.17 \mathrm{~ns}$ \\
Angas Inlet & $0.55 \mathrm{~ns}$ & 0.004 \\
Quarantine Station & \multicolumn{2}{l}{} \\
\hline
\end{tabular}

latisulcatus (at Quarantine Station), or estuarinedependents, i.e. Hyporhamphus regularis (at Angas Inlet) and P. urvillii (at King's Beach).

\section{Spatial variation - influence of site}

There are structural differences in the nearshore assemblages that correlate well with distance into the estuary. e.g. marine stragglers (Ovalipes australiensis, Platycephalus speculator and Cristiceps australis) were dominant at the 'outer' site (Section Bank) but absent or less significant at sites further into the estuary. Although assemblage structure varied between months and years (in terms of changes in abundance of certain species), differences between the sites were confirmed both within years and between years, broadly consistent with patterns detected over 19 mo by Jones et al. (1996). Connolly (1994) detected no difference between assemblages from the 2 waterways comprising the estuary, i.e. the Port River and Barker
Inlet, over 1 yr and concluded that either the former had not been greatly affected or both waterways were equally affected by human activity. In Western Australia, Loneragan \& Potter (1990) demonstrated the influence of site (and month) to be greater than that of year on assemblage structure in the Swan River and within the Peel-Harvey Estuary assemblages at the mouth site were significantly different from those of the inner sites of Peel Inlet and the Harvey Estuary (Loneragan et al. 1986).

\section{Temporal variation - influence of month and year. Evidence of community stability?}

Although change in ecological systems occurs at all temporal scales, our consciousness of variation in the long term is generally less than that in the short term (Valiela 1987). Long-term variability may be subtle and easily masked by large year-to-year variation (Franklin 1987). Whether communities (assemblages) can ever be considered stable is largely dependent upon the temporal scale of any investigation (Connell \& Sousa 1983, Wiens 1984, Giller \& Gee 1986, Wiens et al. 1986). As Williamson (1987) notes, communities are dynamic under constantly changing conditions, and in the long term no community is stable with respect to evolutionary change.

Our study offers the opportunity to consider the concepts of stability and temporal scale in relation to estuarine fish assemblages; the longer term, as used here, refers to periods greater than 3 yr (see Valiela 1987). Although few researchers have had the benefit of such data covering a decade or more, conclusions

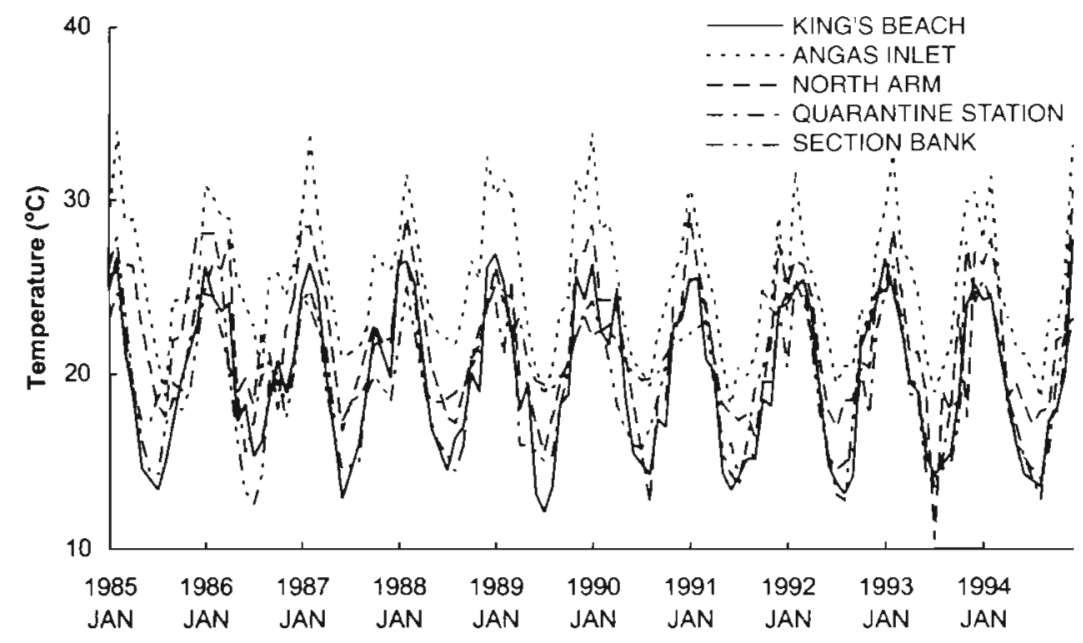

Fig. 5. Monthly water temperatures at all sites, 1985 to 1994 


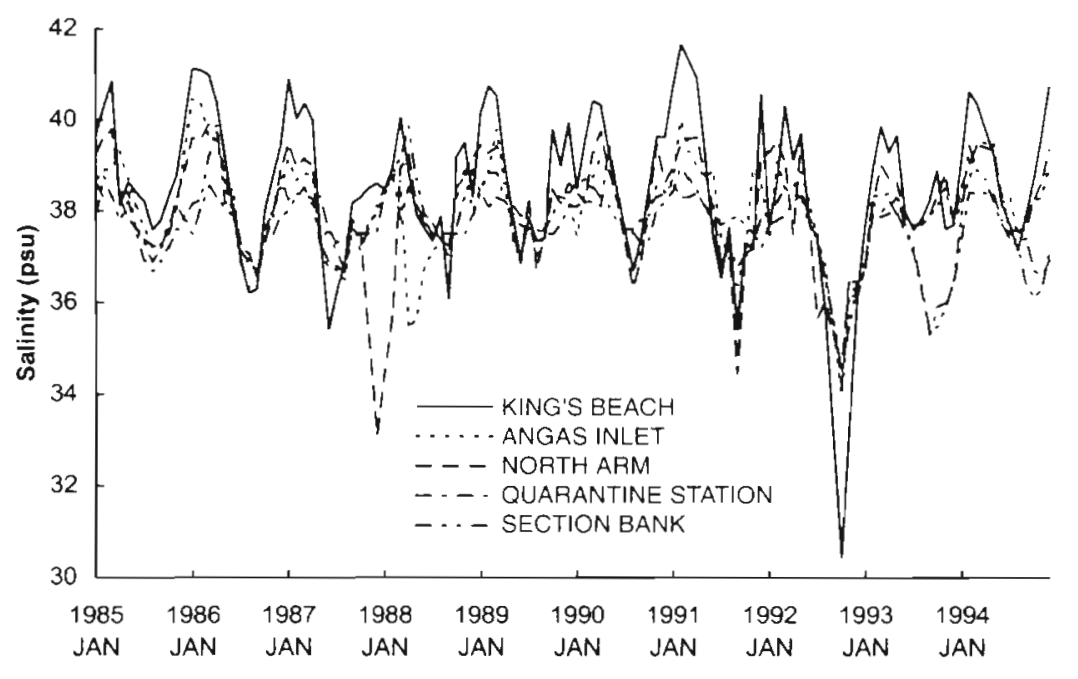

Fig. 6. Monthly salinities at all sites, 1985 to 1994 in any year varies between species from 1 (e.g. Arripis truttacea, Rhombosolea tapirina and monacanthids) to 4 or 5 (Aldrichetta forsteri) (Jones et al. 1996). Analysis of individual species size-distribution data would allow the identification of different cohorts - no discrimination between year-classes is included in our analysis-and their respective seasonal movements. Subsequent testing might then be expected to demonstrate month to be of greater significance within any year.

Annual variation in assemblage structure is apparent over the $10 \mathrm{yr}$ from the significant differences in the fish assemblages detected at all sites except at Quarantine Station. Angas Inlet and North Arm are those most

regarding 'stability in the long term' are frequently to be found in the literature in relation to studies conducted over only 1 or 2 yr (e.g. Livingston et al. 1976, Lasiak 1984).

Despite short-term fluctuations in the abundances of the species determined here to be dominant, assemblages may be considered to maintain some stability (as defined by Southward 1986), with the populations of the dominant species ('core' species of Southward 1986, 'regular' species of Tyler 1971) fluctuating around different equilibria (Williamson 1987). As such, assemblage structure within the Port River-Barker Inlet estuary could be defined as relatively stable between seasons compared with between years.

Such stability, resulting in patterns of species abundance and distribution within estuaries being to some extent predictable between seasons, has been identified as a feature of estuaries and similar habitats (Kennish 1990, Tremain \& Adams 1995). Seasonal changes in species composition and abundance, reflecting both spawning events within the estuary and seasonal movements to and from the adjacent marine environment, would be expected to strongly influence assemblage structure (Livingston et al. 1976, Yoklavich et al. 1990, Potter et al. 1997). Spawning season and arrival time of larvae and juveniles for some species of economic importance in the Port River-Barker Inlet estuary have previously been reported (Jones et al. 1990, 1996). That the ANOSIM2 results showed little significant influence of month at the year level, compared with the site level, is surprising given the seasonal immigrations and emigrations of many species. It is suggested that the consistent presence of many of the dominant species at some sites, in every month, in any year, masks the influence of any monthly immigrations and emigrations. The number of age-classes contributing to the dominant populations affected by the thermal effluent from Torrens Island Power Station and seasonal variation in species composition and abundance has been previously shown (Jones et al. 1996). Relative abundances, reflecting recruitment success, of individual dominant species in any year, and their importance at each site, may help to explain variation in assemblage structure over the 10 yr (Livingston et al. 1976, Morin et al. 1985, Wright 1988, De Ben et al. 1990, Potter et al. 1997).

Overall, the results do not indicate any clear trends in species composition between 1985 and 1994. However, as previously noted, abundances of some species, in particular, Spratteloides robustus, Hyporhamphus regularis, Arenigobius bifrenatus, Nesogobius sp. 3, and Cristiceps australis, demonstrate greater interannual variability. The majority of the dominant species, which may be considered resilient and more stable in the longer term, are estuarine-opportunists,

Table 6. BIOENV results indicating the influence of temperature and salinity. Values are the weighted Spearman rank correlation coefficients for each combination. No test of significance is currently available, results only indicate the nature and magnitude of any relationship

\begin{tabular}{lrrrr}
\multicolumn{3}{l}{ Year Temp. only } & \multicolumn{3}{l}{ Sal. only } & Temp. + sal. Max correlation \\
\hline 1985 & -0.046 & -0.046 & 0.003 & 0.003 \\
1986 & 0.019 & -0.006 & 0.036 & 0.036 \\
1987 & 0.205 & 0.013 & 0.181 & 0.205 \\
1988 & 0.115 & -0.082 & 0.080 & 0.115 \\
1989 & 0.105 & -0.071 & 0.046 & 0.105 \\
1990 & 0.164 & 0.035 & 0.185 & 0.185 \\
1991 & 0.054 & -0.110 & -0.020 & 0.054 \\
1992 & 0.187 & -0.156 & 0.064 & 0.187 \\
1993 & -0.023 & -0.100 & -0.035 & -0.023 \\
1994 & 0.006 & -0.018 & 0.029 & 0.029 \\
\end{tabular}


and to a lesser extent marine stragglers. Such species generally have wider distributions (compared with estuarine-dependent species) and may be considered as having 'open populations' (Giller \& Gee 1986, Young 1995) with broader dispersal capabilities and are possibly less influenced by intrinsic factors within the estuary. For example, both Arripis truttacea and Arripis georgiana spawn off the south coast of Western Australia and variation in recruitment, in South Australia, has been linked with oceanographic and climatic factors (Lenanton et al, 1991, G. K. Jones unpubl. data). In comparison, the more variable, mainly estuarine-dependent species are likely to be 'closed populations' and thereby more directly influenced by natural and anthropogenic factors within the estuary. Factors controlling reproductive activity and recruitment success of many species inhabiting this estuary, including those of economic value, still remain to be investigated.

Ecologists are often hesitant in utilising other sources of potentially valuable biological information (particularly from anecdotal sources, Rose 1997) which may provide useful background for such longer term studies. For example, information regarding changes to recreational catches in the Port River, a popular fishing destination for many South Australians, over last 40 to $50 \mathrm{yr}$ suggests some interesting changes in the more abundant species. Bennett (1997) reported that Liza argentea (not determined to be a dominant species in our study) was the main species caught in the 1930-1940s but had declined in abundance by the early 1960s, apparently to be replaced by Acanthopagrus butcheri (also not dominant here). Large catches of Pseudaphritis urvillii (one of the dominant species in our study) and Scomber australasicus (not recorded in our study) were also more prevalent in the past.

\section{Influence of environmental factors}

Water temperature and salinity were not the principal determinants of patterns in nearshore species composition and abundance in this study. Connolly (1994) avoided sampling the thermally affected areas and concluded distance from open water to be the only environmental factor of importance in matching patterns in the Port River-Barker Inlet fish assemblages. Jones et al. (1996) proposed that water temperature, as a function of distance from the source of thermal effluent from Torrens Island Power Station, directly influenced species distribution and abundance in seasonally different ways.

Water temperature and salinity have been considered the most influential physico-chemical factors determining the distribution and abundance of estuar- ine fish faunas (Haedrich 1983, Kennish 1990) and consequently strong correlations between these factors and species data would be expected (Allen 1982, Horn \& Allen 1985, Potter et al. 1986, Loneragan et al. 1987, De Ben et al. 1990). The Port River-Barker Inlet system is not an estuary sensu stricto, freshwater inputs are minimal and highly variable, and temperature and salinity gradients are less well defined, suggesting the area is a marine embayment rather than an estuary. That species diversity decreases moving away from the mouth is confounding in the apparent absence of such environmental gradients. Fish faunas of other estuaries demonstrate an influence of environmental factors more in keeping with the typical estuarine model (Bell et al. 1984, Loneragan et al. 1986, 1987, De Ben et al. 1990, Loneragan \& Potter 1990, Potter \& Hyndes 1994) while previous studies of marine embayments (Wright 1988, Yoklavich et al. 1991) have identified patterns similar to those found in the Port River-Barker Inlet estuary.

Factors not quantified in this study, including habitat structure (e.g. vegetation and substrate type), depth, degree of wave exposure, distance from open water, turbidity, nutrient levels and heavy metal concentrations, may allow a more thorough explanation of patterns in species distribution and abundance (Edgar \& Shaw 1995b, Jenkins \& Sutherland 1997, Jenkins et al. 1997). Local commercial fishers had suggested that 1991 and 1992 were good. recruitment years for blue crabs Portunus pelagicus and western king prawns Penaeus latisulcatus in Gulf St Vincent and speculated that heavy winter rains, resulting in increased turbidity levels in inshore habitats across the gulf, had reduced predation on these species (M. Kangas pers. comm.). Although this remains to be investigated, salinities reported here support the higher rainfall in 1991 and 1992 , and a peak in abundance of $P$. pelagicus was recorded in 1991.

Connolly (1994) caught more species at seagrass sites on all occasions in the Port River-Barker Inlet while Jones et al. (1996) postulated that the disappearance of seagrass, possibly due to thermal pollution, has resulted in reduced densities of some species at the most affected sites. In Western Port, Victoria, although Edgar \& Shaw (1995a) reported greater numbers of Aldrichetta forsteri collected from seagrass sites (compared with unvegetated habitats), commercial catches actually increased following a period of seagrass dieback (MacDonald 1992). In the Port River-Barker Inlet, A. forsteri was more abundant at the most thermally affected site (Angas Inlet) where seagrass was absent.

The increased presence of Ulva australis within the system (Connolly 1986), linked to nutrient enrichment from sewage effluent, particularly affects the North Arm and King's Beach sites. Both of these sites demon- 
strated significant annual variation in assemblage structure between 1985 and 1994. Changes in the abundance of some species, e.g. Aldrichetta forsteri and monacanthids, may be linked with nutrient-Ulva australis levels, although our data suggest a complex explanation; the latter have dramatically increased in abundance in recent years while the former have declined across all sites. Increased abundance of $A$. forsteri has been linked to nutrient enrichment in the Peel-Harvey estuary, Western Australia, and attributed to increased food availability and protection from avian predation (Lenanton et al. 1984).

Few published data exist regarding the quantity or quality of 'freshwater' inflows to the Port River-Baker Inlet system; however, several creeks and major stormwater drains have historically provided highly variable inputs. Wetlands that receive input from stormwater drains have recently been constructed to the nor theast, east, southeast and south of Barker Inlet and such developments will modify the hydrology of Barker Inlet. Estuarine-dependent species, requiring a more truly estuarine environment, could experience some decline in abundance in the future, as the estuary becomes even more of a marine embayment. Monitoring of the abundances of these species in particular, using this study as a baseline, would allow the effects of any development on the estuarine environment to be identified.

\section{CONCLUSIONS}

Long-term studies are unusual in science (Taylor 1987), particularly in the marine environment. This is due in part to the greater resources such studies require and the conflict between the objectives of scientists and short-term pressures facing resource managers (McAninch \& Strayer 1987). However, most key ecological concepts need long-term data to provide a context against which meaningful hypotheses may be formulated and tested (Franklin 1987).

This study provides some evidence of stability in nearshore fish assemblage structure despite the between-year abundance of some species varying by 1 or 2 orders of magnitude. It is suggested that a major environmental perturbation, such as the recent Barker Inlet wetlands development, may be required to bring about any significant change in the structure of these fish assemblages. Patterns such as those identified in this study cannot be demonstrated by many studies of estuarine fishes, the majority of which are less than $3 \mathrm{yr}$ in duration. Such short-term studies, conducted in this estuary at any period within the term of our study, would have provided a briefer 'snapshot', and may have resulted in quite different conclusions being drawn regarding the variability of certain species and thereby overall assemblage structure.

The data gathered between 1985 and 1994 represent an important baseline against which future research monitoring and specific hypothesis testing may be conducted. Continued sampling, but focussed at 1 or 2 sites only, and over a period withir the year when 'indicator' species would be expected to be abundant, may allow the sampling effort to be reduced, whilst still providing important information regarding the status of the Port River-Barker Inlet's nearshore fishes.

Acknowledgements. Since the early 1980s many people have been involved in sampling the Port River-Barker Inlet estuary's fish fauna, initially as the Research Branch of the South Australian Department of Fisheries and, more recently, the South Australian Research and Development Institute (Aquatic Sciences). Alan Butler is thanked for his advice during data analysis. The manuscript initially improved due to reading by Tony Fowler, Rod Connolly, Dave McGlennon, Rod Lenanton and Dan Gaughan. Further improvements followed the constructive comments of 4 anonymous reviewers. At the suggestion of 1 reviewer, the entire data set resulting from this study is available - in the form of Zipped Excel files - for further investigation, on specific request from the primary author

\section{LITERATURE CITED}

Allen LG (1982) Seasonal abundance, composition and productivity of the littoral fish assemblage in Upper Newport Bay, California. Fish Bull 80:769-790

Bell JD, Pollard DA, Burchmore JJ, Pease BC, Middleton MJ (1984) Structure of a fish community in a temperate tidal mangrove creek in Botany Bay, New South Wales. Aust J Mar Freshw Res 35:33-46

Bennet GR (1997) Fishing the Port River system. South Australian Angler 115:14-18

Butler AJ, Depers AM, McKillup SC, Thomas DP (1977) Distribution and sediments of mangrove forests in South Australia. Trans R Soc S Aust 101:35-49

Clark BM, Bennett BA, Lamberth SJ (1996) Temporal variations in surf zone fish assemblages from False Bay. South Africa. Mar Ecol Prog Ser 131:35-47

Clarke KR, Warwick RM (1994) Change in marine communities: an approach to statstical analysis and interpretation National Environmental Research Council, Plymouth

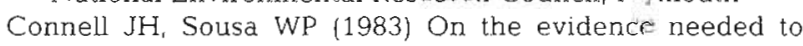
judge ecological stability or persistence. Am Nat 121(6): $789-824$

Connolly RM (1986) Relation of nearshore benthic flora of the Barker Inlet and northern beaches region to pollution sources - with an emphasis on Ulva distribution. South Australian Dept of Environment \& Planning, Adelaide

Connolly RM (1994) A comparison of fish assemblages from seagrass and unvegetated areas of a southern. Australian estuary. Aust J Mar Freshw Res 45:1033-1044

Day JH (1981) The nature, origin and classification of estuaries. In: Day JH (ed) Estuarine ecology with particular reference to Southern Africa. AA Balkema, Rotterdam, p 1-6

De Ben WA, Clothier WD, Ditsworth GR, Baumgartner DJ (1.990) Spatio-temporal fluctuations of demersal fish and 
epibenthic crustaceans in Yaquina Bay, Oregon. Estuaries $13(4): 469-478$

Dye AH (1998) Dynamics of rocky intertidal communities: analyses of long time series from South African shores. Estuar Coast Shelf Sci 46:287-305

Edgar GJ, Shaw C (1995a) The production and trophic ecology of shallow-water fish assemblages in southern Australia. 1. Species richness, size-structure and production of fishes in Western Port, Victoria. J Exp Mar Biol Ecol 194 $53-81$

Edgar GJ, Shaw C (1995b) The production and trophic ecology of shallow-water fish assemblages in southern Australia. 3. General relationships between sediments, seagrasses, invertebrates and fishes. J Exp Mar Biol Ecol 194 107-131

Field JG, Clarke KR, Warwick RM (1982) A practical strategy for analysing multispecies distribution patterns. Mar Ecol Prog Ser 8:37-52

Franklin JF (1987) Importance and justification of long-term studies in ecology. In: Likens GE (ed) Long-term studies in ecology: approaches and alternatives. Springer-Verlag, New York, p 3-19

Gibson RN, Ansell AD, Robb L (1993) Seasonal and annual variations in abundance and species composition of fish and macrocrustacean communities on a Scottish sandy beach. Mar Ecol Prog Ser 98:89-105

Giller PS, Gee JHR (1986) The analysis of community organization: the influence of equilibrium, scale and terminology. In: Gee JHR, Giller PS (eds) Organization of communities - past and present. Blackwell Scientific Publications, Oxford, p 519-542

Gomon MF, Glover JCM, Kuiter RH (1994) The fishes of Australia's south coast. State Print, Adelaide

Grossman GD (1986) Long term persistence in a rocky intertidal fish assemblage. Environ Biol Fishes 15(4):315-317

Haedrich RL (1983) 7. Estuarine fishes. In: Ketchum BH (ed) Ecosystems of the world. 26 Estuaries and enclosed seas. Elsevier Scientific Publ Co, Amsterdam, p 183-207

Hillman RE, Davis NW, Wennemer J (1977) Abundance, diversity and stability in shore-zone fish communities in an area of Long Island Sound affected by the thermal discharge of a nuclear power station. Estuar Coast Mar Sci 5:355-381

Horn MH (1980) Diel and seasonal variation in abundance and diversity of shallow-water fish populations in Morro Bay, California. Fish Bull 78:759-770

Horn MH, Allen LG (1985) 8. Fish community ecology in southern California bays and estuaries. In: Yáñez-Arancibia A (ed) Fish community ecology in estuaries and coastal lagoons: towards an ecosystem integration. DR (R) UNAM Press, México City, p 169-190

Humphries P, Potter IC, Loneragan NR (1992) The fish community in the shallows of a temperate Australian estuary: relationships with the aquatic macrophyte Ruppia megacarpa and environmental variables. Estuar Coast Shelf Sci $34: 325-346$

Hutchins B, Swainston R (1986) Seafishes of southern Australia. Swainston Publ, Perth

Jenkins GP, Sutherland CR (1997) The influence of habitat structure on nearshore fish assemblages in a southern Australian embayment: colonisation and turnover rate of fishes associated with artificial macrophyte beds of varying physical structure. J Exp Mar Biol Ecol 218:103-125

Jenkins GP, May HMA, Wheatley MJ, Holloway MG (1997) Comparison of fish assemblages associated with seagrass and adjacent unvegetated habitats of Port Phillip Bay and Corner Inlet, Victoria, Australia, with emphasis on commercial species. Estuar Coast Shelf Sci 44:569-588
Jones GK (1984) The importance of Barker Inlet as an aquatic reserve; with special reference to fish species. SAFIC $8(6)$ : $8-13$

Jones GK, Hall DA, Hill KL, Staniford AJ (1990) The South Australian marine scalefish fishery green paper. South Australian Dept of Fisheries, Adelaide

Jones GK, Baker JL, Edyvane K, Wright GJ (1996) The nearshore fish community of the Port River-Barker Inlet Estuary, South Australia: 1. The effect of thermal effluent on the fish community structure and distribution and growth of economically important fish species. Mar Freshw Res 47(6):785-799

Kennish MJ (1990) Ecology of estuaries, Vol 2. Biological aspects. CRC Press, Boca Raton

Lasiak TA (1984) Structural aspects of the surf-zone fish assemblage at King's Beach, Algoa Bay, South Africa: long-term fluctuations. Estuar Coast Shelf Sci 18:459-483

Lenanton RC, Potter IC (1987) Contribution of estuaries to commercial fisheries in temperate Western Australia and the concept of estuarine dependence. Estuaries 10(1): $28-35$

Lenanton RC, Potter IC, Loneragan NR, Chrystal PJ (1984) Age structure and changes in abundance of three important species of teleost in an eutrophic estuary (Pisces: Teleostei). J Zool Lond 203:311-327

Lenanton RC, Joll L, Penn J, Jones K (1991) The influence of the Leeuwin Current on coastal fisheries of Western Australia. J R Soc West Aust 74:101-114

Livingston RJ, Kobylinski GJ, Lewis FG III, Sheridan PF (1976) Long-term fluctuations of epibenthic fish and invertebrate populations in Apalachicola Bay, Florida. Fish Bull 74(2):311-321

Loneragan NR, Potter IC (1990) Factors influencing community structure and distribution of different life-cycle categories of fishes in shallow waters of a large Australian estuary. Mar Biol 106:25-37

Loneragan NR, Potter IC, Lenanaton RCJ, Caputi N (1986) Spatial and seasonal differences in the fish fauna in the shallows of a large Australian estuary. Mar Biol 92: 575-586.

Loneragan NR, Potter IC, Lenanaton RCJ, Caputi N (1987) Influence of environmental variables on the fish fauna of a large Australian estuary. Mar Biol 94:631-641

Loneragan NR, Potter IC, Lenanaton RCJ (1989) Influence of site, season and year on contributions made by marine, estuarine, diadromous and freshwater species to the fauna of a temperate Australian estuary. Mar Biol 103:461-479

MacDonald CM (1992) Fluctuations in seagrass habitats and commercial fish catches in Westernport Bay and the Gippsland Lakes, Victoria. In: Hancock DA (ed) Recruitment processes. Australian Society for Fish Biology Workshop Proceedings No. 16, Bureau of Rural Resources, Canberra, p $192-201$

MCAninch JB, Strayer DL. (1987) What are the tradeoffs between the immediacy of management needs and the longer process of scientific discovery? In: Likens GE (ed) Long-term studies in ecology: approaches and alternatives. Springer-Verlag, New York, p 203-205

Morin JG, Kastendiek JE, Harrington A, Davis N (1985) Organization and patterns of interactions in a subtidal sand community on an exposed coast. Mar Ecol Prog Ser 27 : $163-185$

Potter IC, Hyndes GA (1994) Composition of the fish fauna of a permanently open estuary on the southern coast of Australia, and comparisons with a nearby seasonally closed estuary. Mar Biol 121:199-209

Potter IC, Claridge PN, Warwick RM (1986) Consistency of 
seasonal changes in an estuarine fish assemblage. Mar Ecol Prog Ser 32:217-228

Potter IC, Beckley LE, Whitfield AK, Lenanton RCJ (1990) Comparisons between the roles played by estuaries in the life-cycles of fishes in temperate Western Australia and Southern Africa. Environ Biol Fishes 28:143-178

Potter IC, Hyndes GA, Baronie FM (1993) The fish fauna of a seasonally closed Australian estuary. Is the prevalence of estuarine-spawning species high? Mar Biol 116:19-30

Potter IC, Claridge PN, Hyndes GA, Clarke KR (1997) Seasonal, annual and regional variations in ichthyofaunal composition in the Inner Severn Estuary and Inner Bristol Channel. J Mar Biol Assoc UK 77:507-525

Rose GA (1997) The trouble with fisheries science! Rev Fish Biol Fish 7:365-370

Southward TRE (1986) The concept and nature of the community. In: Gee JHR, Giller PS (eds) Organization of commuinities - past and present. Blackwell Scientific Publications, Oxford, p $3-27$

Taylor LR (1987) Objective and experiment in long-term research. In: Likens GE (ed) Long-term studies in ecology: approaches and alternatives. Springer-Verlag, New York, p $20-70$

Thomas IM, Ainslie RC, Johnson DA, Offler EW, Zed PA (1986) The effects of cooling water discharge on the intertidal fauna in the Port River Estuary, South Australia. Trans R Soc S Aust 110(4):159-172

Tremain DM، Adams DH (1995) Seasonal variations in species diversity, abundance and composition of fish communities in the Northern Indian River Lagoon, Florida. Bull Mar Sci $57(1): 171-192$

Tyler AV (1971) Periodic and resident components in communities of Atlantic fishes. J Fish Res Board Can 28:935-946

Valiela I (1987) Conditions and motivations for long-term ecological research: some notions from studies on salt marshes and elsewhere. In: Likens GE (ed) Long-term studies in ecology: approaches and alternatives. SpringerVerlag, New York, p 158-169

Editorial responsibility: Otto Kinne (Editor),

Oldendorf/Luhe, Germany
Vance DJ, Haywood MDE, Heales DS, Staples DJ (1996) Seasonal and annual variation in abundance of postlarval and juvenile grooved tiger prawns Penaeus semiulcatus and environmental variation in the Embley River, Australia: a six year study. Mar Ecol Prog Ser 135:43-55

Wiens JA (1984) On understanding a non-equilibrium world myth and reality in community patterns and processes. In: Strong DR Jr, Simberloff D, Abele LG, Thistle AB (eds) Ecological communities: conceptual issues and the evidence. Princeton University Press, Princeton, p 439-4.57

Wiens JA, Addicott JF, Case EJ, Diamond J (1986) Overview: the importance of spatial and temporal scale in ecological investigations. In: Diamond J, Case EJ (eds) Community ecology. Harper \& Row, New York, p 145-153

Williamson $M$ (1987) Are communities ever stable? In: Gray AJ, Crawley MJ, Edwards PJ (eds) Colonization, succession and stability. Blackwell Scientific Publications Oxford, p 353-371

Wright JM (1988) Seasonal and spatial differences in the fish assemblage of the non-estuarine Sulaibikhat Bay, Kuwait. Mar Biol 100:13-20

Yáñez-Arancibia A, Lara-Dominguez AL, Gill SP, Maldonado VI, Abad GMC, Alavarez-Guillen H, Garcia MT, Hernandez DF, Linares FA (1985) 22. Ecology and evaluation of fish community in coastal ecosystems: estuary-shelf interrelationships in the southern Gulf of Mexico. In: YánezArancibia A (ed) Fish community ecology in estuaries and coastal lagoons: towards an ecosystem integration. DR (R) UNAM Press, México City, p 475-498

Yoklavich MM, Cailliet GM, Barry JP, Ambrose DA, Antrim BS (1991) Temporal and spatial patterns in abundance and diversity of fish assemblages in Elkhorn Slough. California. Estuaries 14(4):465-480

Young CM (1995) Maintenance of diversity in communities dominated by open populations: larval dispersal as a natural mitigator of environmental damage. Bull Mar Sci $57(1): 285$

Submitted: June 5, 1997; Accepted: January 7, 1999 Proofs received from author(s): May 10, 1999 